\title{
THE RIGHT TO SAY NO: EXTRACTIVISMS AND TERRITORIAL STRUGGLES
}

\author{
Felipe Milanez \\ Spensy K. Pimentel \\ Antônia Melo \\ Kum'Tum Akroa Gamella \\ Alessandra Korap Munduruku \\ Antenor Vaz \\ Joelson Ferreira
}

${ }^{I}$ Universidade Federal da Bahia, Salvador, BA, Brazil.

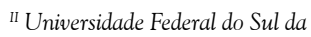
Bahia, Porto Seguro, BA.

III Xingu Alive Forever Movement, Altamira, PA.

IV Povo Akroá Gamella, Web of Peoples and Traditional Communities, Viana, MA.

${ }^{\vee}$ Munduruku people, Federation of Indigenous Peoples of Pará (Fepipa) and Universidade Federal do Oeste do Pará, Itaituba, PA.

VI Specialist in PIACI in South America, Brasília.

VII Higher Knowledge, Universidade Federal de Minas Gerais, and Web of Peoples, Arataca, BA.
Abstract: This article brings the transcription and revision of the roundtable discussion held at the III Latin American Congress of Political Ecology, which aimed to debate different experiences of collective struggles against projects of extraction of natural resource, with the participation of indigenous leaders, traditional communities and activist intellectuals. The narratives shares experiences in processes in which there was collective resistance to extractive-colonial projects and the right to say "no" was put into practice. In general, the presentations discussed the right to say no that emerges beyond the right to consultation, and that has as its assumption the guarantee of collective autonomy over life territories.

Keywords: ILO Convention 169; indigenous peoples; right of consultation; traditional communities; territorial rights.

São Paulo. Vol. 24, 2021

Narratives and Reflections: Decolonial Insurgences and Emancipatory Horizons

DOI: http://dx.doi.org/10.1590/1809-4422asoc20210159vu2021L5NR 


\section{Introduction}

The right to be consulted about projects that affect them is a conquest of Indigenous peoples and traditional communities guaranteed by International Labor Organization Convention 169, of 1989, and reinforced by the United Nations Declaration on the Rights of Indigenous Peoples of 2007. Nevertheless, these prior consultations, which should be free, prior, and informed, are rarely binding. The disrespect for a "no", which occurs systematically, reveals a contradiction of the right to consultation and the imbalance of power in the control of resources and their territories. Thus, the mechanisms for consultation wind up serving to extenuate the unchecked expansion of capital, creating a false impression of a "consented" expansion.

This legal debate is appropriated by communities in a subversive manner, so they can guarantee their existence, autonomy, and sovereignty over their territories. Thus, other concepts emerge from the struggle, such as the basic human right to rebel against tyranny, inscribed in the Universal Declaration of Human Rights. The right to say "no" is located in this last legal recourse and is materialized in direct mobilization actions. To guarantee the right to say "no", even through rebellion, is perhaps one of the final forms of territorial defense populations have when confronting the violence of the nation-state and extractive capitalism.

To advance organically in this concept, a roundtable was organized at the III Latin American Congress of Political Ecology, involving activists and leaders who participate in processes in which there was resistance to colonial-extractive projects and the right to say "no" was placed in practice. Beyond the authors in this report, the other participants in the roundtable were Milton Sanchez, of the Colectivo Guardianas y Guardianes de la Laguna [Guardians of Laguna Collective], and Jorge Nahuel, a Mapuche leader from Argentina.

\section{The experience in Peru}

Milton Sanchez reported on the experience of opposition to the construction of the Conga de La Laguna megaproject, in the Cajamarca, region in Peru. The contamination generated by the project affected the local economy, milk production, decreased the water supply and impacted the health of residents - the region has one of the highest rates of stomach cancer in the country. Financed with international and Peruvian capital, the project is dedicated to exports to China, and exploits a region of water sources that are vital to the region. Approximately 196 thousand tons of contaminated waste have already been dumped in this territory. After 26 years of mineral exploitation, the region rose 
from the fourth to the first among the poorest provinces in Peru.

The exploitation began at Lagoa Yanacocha, which means black water. The lake no longer exists, and the company took the name of the lake. A satellite image reveals the destruction at the site of the lake, the progress they desire. The river was transformed into four pipes. After the mining, these pipes return the effluent to the community. The police conduct security in the region, and it is very difficult to enter to see what is happening. Due to contamination from heavy metals, deaths of animals have been registered. The mine is already much larger than the city itself, which has 200,000 residents. And the mining company is proposing an expansion.

Since no one consulted us, we organized and said "no!", through the action of the Guardiões das Lagoas [Guardians of the Lakes]. The response of the state and the company was to militarize the conflict. A special police mission invaded the territory for eight months. They took the Celedin plaza. They shot at us and killed five colleagues. And, given the resistance, decided to stop the expansion.

Stopping extractive projects has a long history in Peru. In 2002, we had to organize a self-consultation. That is, a consultation that was not conducted by the government, but by the community. And this led to the project being stopped after $93 \%$ of the people said no. The government then came to reject the self-organized consultations, and the population began to demand a law for popular consultations. This law was approved in 2011. But it was not the solution. What happens is that the state and the companies do not consult everyone. The companies and state decided who is Indigenous and who will be consulted. After the consultation law, all the projects for which there were consultations were approved.

The same thing took place with hydrocarbons, so that the government and the companies use this consultation law to guarantee benefits for themselves, to legitimize the projects.

But, in Peru, we resisted. In Guatemala and in Mexico various peoples are observing the experience of resistance in Peru, to try to do the same thing. An encounter with the Indigenous peoples of Central America was held, and took the position that they will not submit, they will not accept these consultations that only legitimate projects. The key word is no: we will not accept that they come with their own tools to manipulate and impose the projects on our territories.

\section{The Mapuche struggle in Argentina}

Jorge Nahuel is from the province of Neuquén, a region that for five years has suffered from fracking, a technique for oil and gas exploration that requires injecting chemical substances into the earth to extract oil and gas. This tech- 
nique, which reaches some three thousand meters below the surface, is particularly harmful because it contaminates water, and thus the population, with heavy metals and other chemical compounds. In Argentina, regulation of consultations without the guaranteed right to consent, to say "no", was not accepted. Jorge explains that the Mapuche were a free nation 130 years ago, which allowed them to perceive the type of territorial aggression imposed by fracking, promoted by the Argentine state, with compliance from the legislature and judiciary, and multi-national companies. The Mapuche leaders, who simply fulfill their responsibility as Indigenous authorities, suffered when their movement against fracking was criminalized, and they were accused of illegal association and other charges. Jorge understands that the struggle against this type of exploitation goes beyond Mapuche territory, and involves an understanding that human beings are integrated to water, soil, air and land.

\section{The protocol for consultation of the Munduruku, by Alessandra Ko- rap Munduruku}

I am Alessandra, of the Munduruku people, in western Tapajós. Kin, colleagues, your struggle strengthens ours as well, we learn a lot when we hear other people speaking. Sometimes we feel weak, and suddenly we feel strong as well.

The Munduruku people prepared a protocol for consultation, because the federal government had already decided to build a hydroelectric dam at São Luís de Tapajós, and already had researchers and national security forces within the territory. We had no right to speak, to go to the streets, precisely because they had already decided to build the dam.

When the protocol was drafted, we spoke not only of the Munduruku people, we spoke of people in general who would be impacted, of those who live along the rivers, of the traditional communities, and there are many communities, the people of MontanhaMongabal, we allied with them as well.

And this strengthened us. The government wanted to buy the leaders, like they did at Belo Monte: they promised cars, boats, money to build shacks. And we saw this wasn't good. The experience that we had when we were there at Belo Monte also strengthened us, we saw what was happening. Because we could commit the mistakes they made.

When we made the protocol it was precisely to be heard inside the village. We actually did not let the government enter our territory, because there is a weapon they use quite readily, which is to lie. They do not know how to hear the truth, they do not know how to listen, they do not know how to hear no. They have to learn to hear no, 
this is the problem of the government and the companies.

We cannot hide, we also need to speak, because this is what they do, they only speak and go away. And if necessary, our meeting lasts until two in the morning. When they say they need to speak with the leaders, only three? No, we are 100, 100 will go to the meeting. This is what we demand, that we be heard. The wise ones should be consulted, the elders, the pajés [shamans], the one who knows how to tell a story, who knows traditional medicine, roots, leaves, who knows the sacred places, the caciques [chiefs], guerreiros, guerreiras [militants], leaders, teachers and healthcare agents, women. In the past, women were not heard and today there are already many of us. Students, college students, Munduruku teachers, they should also be consulted.

How do we reach our decision? When the project affects all of us our decision is collective, the government cannot only consult a part of the Munduruku people. They cannot, for example, consult only the Munduruku of the Middle [Tapajós], or only those of the Upper [Tapajós]. No association decides or responds for the Munduruku people. The decisions of our people are taken in a General Assembly, which are convoked by our caciques. At the assemblies, we discuss and reach a consensus. If necessary, we debate a lot, we vote. If there is no consensus, the majority [rules], and with the people we hope to promote respect for our decision, we do have veto power. Sawê!

We were able to stop the railroad that carried soybeans, we were able to stop the forest concession, 200 thousand hectares of wood from our territory. We stopped the large hydroelectric project at São Luís do Tapajós. They said that we are stubborn, a pest, a stone in their shoe, but we will continue being all of this that they say, because we will not give away our land.

This is for the future generations, what I leave is for them. If it is deforested, we will plant the forest, we will plant, we will fish. The consultation protocol is the only weapon that we have now. If it is not respected, then the only option is to occupy.

\section{The resistance by Xingu Vivo, by Antônia Melo}

I am from the Movimento Xingu Vivo Para Sempre [Xingu Alive Forever Movement], created in 2008 to promote the union of social movements and Indigenous peoples of Xingu against the construction of the Belo Monte hydroelectric dam. We want to say to our friend in struggle our warrior friend, of Peru and Argentina, I am watching this film, I saw it at Belo Monte, it was just the same. Only the location of these cursed projects are different, but the terrible practice of the massacre, of the violation of rights, is everywhere.

It's like when he said that their struggle in defense of territory has gone on for a long time: ours as well. In the 1980s, during the military dictatorship, there was a 
project called Cararaô, a complex with six dams on the river, which would flood almost 20,000 km, 12 indigenous lands, as well as isolated indigenous groups, and would displace hundreds and thousands of people. Then, in 1989, the Indigenous Kayapó held a big meeting, with the support of their allies, the indigenous movement UNI, the Pro-Indian Commission and the Catholic Church. They called on the government to say "NO" in a large meeting in Altamira. The indigenous woman Tuíra, in a warrior gesture, put her machete in the face of the government representative and the company Eletronorte and called him a liar, because he said that the Indigenous lands would not be flooded, but they had already studied the project and knew that they would be. With international and national pressure and the struggle of the indigenous peoples, the cancellation of the resources by the World Bank, the project was shelved by the government.

In 2000, the government of [President] Fernando Henrique Cardoso announced it would build a large development project for the country, Belo Monte. The government said that it would build the plant, that it wouldn't affect the Indigenous lands, that it would move the course of the river. It really did this, it changed the course of the Xingu River, 20 kilometers, bypass channel that takes water from the Xingu River to the socalled Belo Monte powerhouse.

Saying no to this project is a struggle of more than 30 years. Unfortunately, the LULA government overruled the laws, indigenous rights and the affected population in general, saying that it would build it, ignoring all rights. Just see the shamelessness, you know what they did, with Funai involved? Together with the company, they showed a design of Belo Monte, the dams, the benefits - a few pretty houses, a pretty PowerPoint -so that the Indigenous in the villages would learn about the project, that's all. And then they used these photos and these signatures of Indigenous communities to say that they had been consulted.

There were lots of petitions, many campaigns, but the so-called "government of the people" ignored everyone, it was disgraceful. But, the struggle goes on. Belo Monte is ready, and now? Was it worth it? Sure it was, we had a number of victories. First, the victory of not letting Belo Monte stay hidden under the carpet. We denounced it, and today the whole world knows: Belo Monte fed corruption, laundered lots of money. This model doesn't serve us, it just leaves poverty, misery. "Development" for us is a lie.

Belo Monte today is built, with many problems: the threats continue, there is a lot of violence. It is a project that is not sustainable, it is inviable and will not generate the energy that they said it would, it will dry up more than 100 kilometers of the Volta Grande do Xingu, where there are villages, Indigenous communities and those who live along the rivers.

Another project is Belo Sun, a Canadian mining company that wants to locate along the Xingu River, where there is already a lack of water. They will get water from 
the Xingu for this mining company, they will dig for 12 years, more than 50 tons of gold, 200 meters deep, with piles of tailings, of stone, mud, taller than the biggest buildings in São Paulo. It is a monstrosity on the riverside, near Belo Monte's Pimental Dam. We are fighting to mobilize internationally with a campaign, to show the monstrosity of a project of unprecedented impacts much worse than the crimes of the criminal companies of Mariana and Brumadinho

These are the disasters that these governments and companies bring to us in the Amazon, in Latin America, and we must respond. Our rivers are being contaminated, the people are being assassinated by these companies or with their support. We need a large alliance, a Pan-Amazonia of Latin peoples.

When will we, in this country, say NO and be respected! To say: not here, we are the owners of this territory for our livelihood and good living! This development model is no good, it destroys.

\section{Respect for isolated peoples, by Antenor Vaz}

My talk will be informative. I will try to review some information about the Isolated Indigenous Peoples and those of Recent Contact (PIIRC). I want to outline some concerns about these peoples who have still not established contact. Why do they refuse contact, preferring isolation?

These peoples are threatened by a trap that is called a development model. The countries of South America with registers of isolated Indigenous peoples, without permanent contact, are: Venezuela, Colombia, Ecuador, Peru, Bolivia, Paraguay and Brazil. In 2005 there were, in all of South America, 51 confirmed records of isolated peoples and 33 awaiting confirmation. In 2019, there are 66 confirmed peoples in situations of isolation and 119 awaiting confirmation. Therefore, there was a large increase in information between 2005 and 2019. These records are the result of the work of protection conducted by organized civil society, based in Indigenous organizations or their allies .

The agro-extractiv-export development model, implanted in all the countries of South America, is supported and financed by large economic corporations and banks that are allied to states to implement large projects. We have listed some 70 large companies of Brazilian and international capital that finance and implement projects that are in the Amazon, the Cerrado and the Grande Chaco and that directly affect or indirectly affect the isolated indigenous peoples. We highlight Chinese, Canadian, US companies, banks like BNDES [Brazilian National Development Bank], the World Bank, etc., financing road construction, agribusiness, oil exploration, hydroelectric dams, transmission lines, mining, tourism and lumbering.

To conclude, these isolated Indigenous peoples have their way to say no: "we 
do not want to relate with you". This isolation is not because they think the forest is beautiful, nature is beautiful. Their isolation says: "we are not interested in your model of society". It is a cultural and ideological resistance. The centuries old history of these people with Western society was a history of death and massacres. The main enemy of these Indigenous peoples - I am speaking in the case of isolated Indigenous peoples, emphasizing that I do not represent them - is our development model.

Of the seven countries, three have specific laws to protect these peoples: Brazil, Peru and Colombia. The others, such as Venezuela and Paraguay, do not have a legal reference for their protection. Bolivia does, but it was never implemented. But the countries were never able to truly protect the isolated Indigenous peoples, only minimally decrease that which they caused and cause. And history constantly repeats itself.

\section{Peoples and Communities of Maranhão, by Kum’Tum Akroa Gamela}

I am Kum'Tum, of the Akroá Gamela people, and I come here as well in the name of the Web of Traditional Peoples and Communities of Maranhão. The Web is not a space of representations, it is also not an organization of entities. We are peoples and communities that struggle firmly in defense of our territories. Everyone is welcome as long as they have this perspective of weaving the struggle.

Through our ancestors we recognize and feel that everyone and everything - water, earth, minerals, plants, animals, humans, spirits - we are all interlinked. We are threads of the same web of life. However, mining projects, dams, windand solar-parks, monoculture of soybeans, eucalyptus, sugarcane, are gravely harming our Mother-Earth, poisoning our waters, killing the forests and the inhabitants in a form and at a speed that their consequences cannot be fixed.

It is necessary to understand and respect that each element of nature has a spirit that protects it and lives within it. When these places are destroyed, its guardians wander, and their suffering threatens the harmony of the entire web. The sky will fall on all of us, as Yanomami shaman Davi Kopenawa teaches us.

The Akroá Gamella people, after centuries of attempts at genocide, became silent to continue existing at our pajelança ceremonies, at the Festa de Bilibeu, in the Serra de Velho, in the narratives about João Piraí, in the art of weaving guarimã, of making flour, of fishing by hand, in the act of eating juçara. The state placed a stone on us, but our ancestral roots are alive and nourishing our lives. Thus, we are able to join forces to cast off the stone, as Cotap teaches us, a leader of our people, to say to the world that we exist and we must be respected.

In 2014, people discovered that there was one more high tension transmission line being built on our territory, by the Companhia Energética do Maran- 
hão, and at that point [the company] began a series of attempts to seduce and harass our leaders to allow the project. In the following year, we denounced these illegal attempts to the Federal Public Ministry and requested that something be done. Even so, the project continued. The company filed suit to guarantee the continuity of the project even with the illegalities, under the allegation of public interest. The measure was granted, but we protested to the judge who promptly reconsidered the injunction and called for a hearing to hear all the parties involved. We had the judge understand that the river is part of our identity. Therefore, all and any action that can have a negative impact should be discussed with the whole community.

During the legal action we were called "supposed Indians", "without behavioral boundaries" and accused of impeding progress and development, reproducing the same old genocidal discourses and practices. Since our ancestral roots we have resisted, and we resist because lives cannot be compensated or mitigated. And we are not only speaking of human lives.

We resist until now. For how long? We know that the state has the brute strength and could send security forces at any moment, in name of the "public interest" to guarantee implantation of the project over bodies. Even if we are abused, we continue to be seeds irrigated by our ancestral memory and by the struggles made by the original peoples from all the places on Earth.

\section{The Web of Peoples, by Joelson Ferreira}

I am son of Ogum, from war, I no longer have a problem with this and I will tell you: we are seeing a total war against our people. In the MST [Landless Farmers Movement], I was lucky enough to travel to China, Korea, the Philippines, Venezuela and it is the same story as all of us here. Everywhere, the World Bank, the state banks, the progressive governments, all kinds of governments, have the same language of this so-called "development", which is the destruction of the local, original, black peoples.

There is no option: we must declare a war of defense against our enemies, we must return to discuss important issues. Today it is a heresy to speak of the war against the empire and that, in the twenty-first century we must be anti-capitalists, anti-imperialists. We, in Brazil, must confront the fifth neocolonization of capital: it is financial capital, which previously was in money-lending and now returns here to buy everything in our territories.

We, in the Web of Peoples, we are not a movement, we are a group that is seeking alliance for those who are in permanent struggle, and with some principles: first, it is the struggle for earth and for territory - it is urgent, it is necessary and who doesn't 
discuss this is losing their identity, their territory and there is no other way; second, the struggle for the defense of sovereignty, that is, of the existence of our territory. It's not subsistence, its existence.

We must build an economy beyond capital, there are no short cuts. We must build our schools, to educate our children, our youth for the future that is coming. If we want autonomy, we must defend the creole seeds, the native seeds and share them with the whole world.

We must revive the cosmovisions of the original peoples, of the Black people who came from Africa, and as Darcy Ribeiro said, mix everything in this pot. We must build an arc of alliances with the peoples. We did not create the war, they imposed it. We must turn off these cell phones, these miserable machines that are controlling our brains and our souls, so we can try to feel something, as Che Guevara said, at least indignation. The Zapatistas still exist because, when everyone said that weapons had no value, they picked up weapons, and today they are there as a society. It is also necessary to understand that our intelligence is greater than any type of weapon and to understand that the people's economy even involves creating a dialog with urban society.

We must build an alliance on this concrete plane, because, if not, we will not dia$\log$ with the people in the fields, who no longer believe in anyone. When we arrive with the seeds and with the plants, it is extraordinary, everyone wants the seed and a plant. When we speak of the issue of the chocolate that we are producing today on our territories, it is concrete. We must also begin to discuss that we must become radical. And being radical means that we must build a life project and say: this is our project, this is our territory, this is our earth and it is here we want to stay, and here that we want to live and we are able to create our autonomies and our liberty.

\section{Conclusions: The autonomy of the peoples}

The statements above reveals that the "right to say no" is only one of the components of the broader claims for autonomy. As the Mixtecan intellectual López Bárcenas affirms, autonomy does not always appear with this name, but comes from the "same utopian projects, which involve peoples with complete rights, territories, natural resources, their own forms of organization and of political representation" (2007: 9-10).

The statements coincide to indicate that the moment of arrival of these projects is of demystification of the supposedly "neutral" character of the state. Ultimately, the challenge is to construct the overcoming of the relations of "internal colonialism" that wants to maintain the "relations of subordination" that have been established since the European invasion (López Bárcenas, 2007: 52). 
As Antonia Mello reminds us: "the government, the companies, will never listen and do not know how to hear 'no', because they do not defend the people. We must defend ourselves".

\section{Acknowledgements}

This round of dialogue was supported by CAPES, CNPQ and the Rosa Luxemburg Foundation. The editors would like to thank Júlia Mota de Brito for the transcription of the round table. The translation of this paper was supported by the British Academy funded project (SDP2\100278) "'Sustainable' development and atmospheres of violence: experiences of environmental defenders" and the University of Sussex/ Research England/Global Challenges Research Fund (IDCF1- G2626-08), a collaboration between the Federal University of Bahia (UFBA) and the University of Sussex and run by Fapex.

\section{References}

LÓPEZ BÁRCENAS, Francisco. Autonomias Indígenas en América Latina. México DF, MC/Coapi, 2007. 
Felipe Milanez

$\checkmark$ felipemilanez@ufba.br

ORCiD: https://orcid.org/0000000347736691
Submitted on: 06/07/2021

Accepted on: 02/09/2021

2021;24e:0159

\section{Spensy K. Pimentel}

spensy@ufsb.edu.br

\section{Antônia Melo}

$\varangle$ xinguvivo@yahoo.com.br>

\section{Kum’Tum Akroa Gamella}

$\varangle$ vieiraserejo@yahoo.com.br

\section{Alessandra Korap Munduruku \\ $\square$ alessandracorape@gmail.com}

Antenor Vaz

$\varangle$ uinala@yahoo.com

\section{Joelson Ferreira}

$\varangle$ solange@cabruca.org.br

How to cite: MILANEZ, F.; PIMENTEL, S. K., MELO, A. AKROA GAMELLA, K.T., KORAP, A., VAZ, A., FERREIRA, J. The Right to Say No: Extractivisms and Territorial Struggles. Ambiente \& Sociedade. São Paulo, v. 24, p. 1-12, 2021. 


\title{
O Direito de Dizer Não: Extrativismos e Lutas Territoriais
}

\author{
Felipe Milanez \\ Spensy K. Pimentel \\ Antônia Melo \\ Kum'Tum Akroa Gamella \\ Alessandra Korap Munduruku \\ Antenor Vaz \\ Joelson Ferreira
}

São Paulo. Vol. 24, 2021

Narrativas e reflexões: Insurgências Decoloniais e Horizontes Emancipatórios
Resumo: Este artigo traz a transcrição e revisão da roda de conversa realizada no III Congresso Latino-Americano de Ecologia Política, que teve como objetivo debater diferentes experiências de lutas coletivas frentes a projetos de extração de recursos naturais, com a participação de lideranças indígenas, de comunidades tradicionais e intelectuais ativistas. As experiências relatam processos em que houve resistência coletiva a projetos extrativos-coloniais e o direito de dizer "não" foi colocado em prática. De forma geral, as apresentações discutiram o direito de dizer não que emerge para além do direito à consulta, e que tem como pressuposto a garantia da autonomia coletiva sobre os territórios de vida.

Palavras-chave: Convenção 169 da OIT; povos indígenas; direito de consulta; comunidades tradicionais; direitos territoriais.

Como citar: MILANEZ, F; PIMENTEL, S. K., MELO, A. AKROA GAMELLA, K.T., KORAP, A., VAZ, A., FERREIRA, J. O Direito de Dizer Não: Extrativismos e Lutas Territoriais. Ambiente $\mathbb{\&}$ Sociedade. São Paulo, v. 24, p. 1-12, 2021. 


\title{
El Derecho a Decir No: Extractivismos y Luchas Territoriales
}

\author{
Felipe Milanez \\ Spensy K. Pimentel \\ Antônia Melo \\ Kum'Tum Akroa Gamella \\ Alessandra Korap Munduruku \\ Antenor Vaz
}

São Paulo. Vol. 24, 2021

Narrativas y reflexiones: Insurgencias Decoloniales y Horizontes Emancipatórios
Resumen: Este artículo trae la transcripción y revisión de la mesa redonda realizada en el III Congreso Latinoamericano de Ecología Política, que tuvo como objetivo debatir diferentes experiencias de luchas colectivas contra proyectos de extracción de recursos naturales, con la participación de líderes indígenas, comunidades tradicionales y activistas intelectuales. Las experiencias relataron procesos en los que hubo una resistencia colectiva a los proyectos extractivos-coloniales y se puso en práctica el derecho a decir "no". En general, en las ponencias se habló del derecho a decir no, que surge más allá del derecho a la consulta, y que tiene como fundamento de garantizar la autonomía colectiva sobre los territorios de vida.

Palabras-clave: Convenio 169 de la OIT; pueblos indígenas; derecho de consulta; comunidades tradicionales; derechos territoriales.

Como citar: MILANEZ, F; PIMENTEL, S. K., MELO, A. AKROA GAMELLA, K.T., KORAP, A., VAZ, A., FERREIRA, J.. El Derecho a Decir No: Extractivismos y Luchas territoriales. Ambiente $\mathbb{\&}$ Sociedade. São Paulo, v. 24, p. 1-12, 2021.

DOI: http://dx.doi.org/10.1590/1809-4422asoc20210159vu2021L5NR 